
аспірант,

Волинський національний університет імені Лесі Українки, кафедра міжнародних економічних відносин, м. Луцьк; ORCID ID 0000-0002-3646-7687,

https://doi.org/10.29038/2411-4014-2020-04-63-70 e-mail:Olehpodzizej@gmail.com

\title{
СУТНІСТЬ ТА ЗМІСТ КОНКУРЕНТОСПРОМОЖНОСТІ ОБ'ЄДНАНИХ ТЕРИТОРІАЛЬНИХ ГРОМАД В УМОВАХ ІНКЛЮЗИВНОГО РОЗВИТКУ
}

Конкурентоспроможність об'єднаних територіальних громад (ОТГ) є ключовим елементом формування стратегічного плану їх розвитку. Тому адміністративно-економічна реформа, яка проводиться в Україні, повинна забезпечити необхідні умови для формування та розвитку територіальних громад. Об'єднані територіальні громади повинні функціонувати відповідно до принципів ефективного господарювання, необхідно враховувати усі затрати та вигоди від реалізації програм розвитку власної конкурентоспроможності. Результатом формування такої конкурентоспроможності $є$ підвищення ефективності функціонування територіальних громад.

У статті розглянуто специфіку формування підходів до розуміння сутності конкурентоспроможності ОТГ, зокрема - конкретизовано фактори та чинники, що впливають на їх конкурентоспроможність. Визначено особливості взаємозалежності розвитку ОТГ від специфіки їх регіонального територіального розміщення.

Доведено, що забезпечення ефективного функціонування ОТГ в сучасних умовах потребує налагодження та становлення передумов щодо інклюзивного розвитку територій на основі забезпечення дотримання ключових факторів формування їх конкурентоспроможності.

Ключові слова: ОТГ, конкурентоспроможність, конкуренція, чинники конкурентоспроможності, регіональний розвиток.

Подзизей Олег, аспирант,

Волынский национальный университет имени Леси Украинки, кафедра международных экономических отношений, г. Луцк

\section{СУЩНОСТЬ И СОДЕРЖАНИЕ КОНКУРЕНТОСПОСОБНОСТИ ОБЪЕДИНЕННЫХ ТЕРРИТОРИАЛЬНЫХ ОБЩИН В УСЛОВИЯХ ИНКЛЮЗИВНОГО РАЗВИТИЯ}

Конкурентоспособность объединенных территориальных общин (ОТО) является ключевым элементом формирования стратегического плана их развития. Поэтому административно-экономическая реформа, которая проводится в Украине, должна обеспечить необходимые условия для формирования и развития территориальных общин. Объединенные территориальные общины должны функционировать в соответствии с принципами эффективного хозяйствования, при этом необходимо учитывать все затраты и выгоды от реализации программ развития собственной конкурентоспособности. Результатом формирования такой конкурентоспособности является повышение эффективности функционирования территориальных общин.

В статье рассмотрено специфику формирования подходов к пониманию сущности конкурентоспособности ОТО, в частности - конкретизируются факторы, влияющие на конкурентоспособность. Определены особенности взаимозависимости развития ОТО от специфики их регионального территориального размещения.

Доказано, что обеспечение эффективного функционирования ОТО в современных условиях требует налаживания и становления предпосылок инклюзивного развития территорий на основании обеспечения безусловного соблюдения формирования ключевых факторов их конкурентоспособности.

Ключевые слова: ОТО, конкурентоспособность, конкуренция, факторы конкурентоспособности, региональное развитие. 


\section{Podzizei Oleh, \\ PhD student, \\ Lesya Ukrainka Volyn National University, Department of International Economic Relations, \\ Lutsk}

\section{ESSENCE AND CONTENT OF UTC COMPETITIVENESS IN THE CONDITIONS OF INCLUSIVE DEVELOPMENT}

United territorial communities (UTC) competitiveness is a key element in forming a strategic plan for their development. Therefore, the administrative and economic reform carried out in Ukraine should provide the necessary conditions for the formation and development of territorial communities. UTCs must operate in accordance with the principles of efficient management, it is necessary to take into account all the costs and benefits of implementing programs to develop their own competitiveness. This The result of the formation of such competitiveness is to increase the efficiency of territorial communities.

The article considers the specifics of the formation of approaches to understanding the essence of UTC competitiveness, in particular - specifies the factors and factors influencing competitiveness. Peculiarities of interdependence of UTC development on the specifics of their regional territorial location are determined.

Peculiarities of the current stage of reforming the system of local self-government, as well as the related transformation of the principles of economic policy of local governments in Ukraine, requires a review of all systemic factors that determine the functioning of the grassroots administrative and economic system. In this aspect, a fundamentally new, as well as a basic element of such a system are united territorial communities (UTC), which are formed in Ukraine in the process of implementing a new state policy - decentralization of local government and increasing the role of local communities in meeting their socio-economic development.

Thus, the availability of a specific list of qualitative factors for assessing the competitiveness of UTC allows the local community to assess them and determine the number of parameters and based on this analysis to form a strategy to achieve the necessary competitiveness indicators, which will form a community development strategy. On the other hand, without access to a system for assessing and analyzing such parameters, local communities will not be able to set clear goals and objectives for investment or infrastructure development, which, of course, will not allow them to form an appropriate level of competitiveness.

Keywords: UTC, competitiveness, competition, competitiveness factors, regional development.

Постановка проблеми. Особливості сучасного етапу переформатування системи місцевого самоврядування, а також, пов’язаної з цим трансформації принципів економічної політики органів місцевого самоврядування, що відбувається в Україні, потребує перегляду усіх системних факторів, які визначають особливості функціонування низової ланки адміністративно-економічного устрою держави. В даному аспекті принципово новим, а також базовим елементом такої системи стають об’єднані територіальні громади (ОТГ), які формуються в Україні в процесі реалізації нової державної політики - децентралізації органів місцевого самоврядування та підвищення ролі місцевих громад в забезпеченні потреб їх соціально-економічного розвитку.

Наслідком таких трансформацій є не лише економічна децентралізація системи місцевого самоврядування, але й зростання фінансово-економічних можливостей цієї системи загалом і ОТГ, як іiі складової зокрема. Відповідно, територіальні громади в таких умовах набувають особливого значення не лише, як елементи економічної системи регіону, але й як самостійні і вагомі гравці на місцевому ринку, котрі за рахунок наявних ресурсів можуть формувати і стимулювати попит на певні види ресурсів або послуг. Таким чином, новостворені ОТГ є не лише споживачами, які за рахунок наявних фінансових потоків забезпечують потреби власного розвитку, але вони виступають саме економічними агентами, котрі формують умови інклюзивного розвитку відповідних територій за рахунок фінансування належних витрат, інвестування наявних фінансових ресурсів, а також залучення та переспрямування інвестиційних потоків на місцевому рівні згідно потреб місцевого населення та власного розвитку загалом.

Аналіз останніх досліджень і публікацій. Дослідженням процесів та особливостей розвитку економічних систем регіонального рівня присвячені праці багатьох авторитетних дослідників та науковців. Зокрема, значний внесок у вивчення даного питання здійснили такі зарубіжні дослідники, 
як П. Р. Кругман та М. Обстфельд [14], Р. Е. Лукас, Н. Стокей та Е. Прескотт [15], Д. Родрік [16], Т. В. Шульц [17] та багато інших. Варто також звернути увагу на дослідження, присвячені визначенню особливостей регіональної та виробничої конкурентоспроможності, значний внесок в які здійснили такі вчені, як Р. Р. Білик [13], Л. Г. Бальцерович [1], 3. С. Варналій та О. П. Гармашова [3], В. І. Захарченко та С. В. Захарченко [6], М. Портер [9] та інші.

Загалом економічна наука має достатньо напрацювань у сфері регіональної економіки та конкурентоспроможності. Проте особливості адміністративно-територіальної реформи в Україні, які призвели до створення об'єднаних територіальних громад, потребують поглибленого вивчення специфіки формування конкурентоспроможності ОТГ.

Виділення невирішених раніше частин загальної проблеми. Практика досліджень економічної політики органів місцевого самоврядування як в Україні, так і в інших країнах світу має усталені та дієві підходи до оцінки ефективності їх функціонування. Тому, за допомогою внесення певних коректив, зумовлених специфікою країни, впровадження таких моделей дозволяє належним чином використати наявний інструментарій для визначення конкретних параметрів діяльності ОТГ, як адміністративно-управлінських інституцій, в системі управління економічним розвитком регіону або місцевої громади. Тому, на нашу думку, потреба пошуку нових систем оцінювання діяльності ОТГ в аспекті досягнення належного рівня управління соціально-економічною системою, наразі відсутня.

Виклад основного матеріалу. Новостворена система об'єднаних територіальних громад за своєю функціональністю $є$ доволі гнучкою і дозволяє формувати окрему політику своєї діяльності для кожного окремого випадку. Якщо раніше райони або сільські ради, які входили до їх складу, діяли в суворо визначених межах адміністративного управління та бюджетного кодексу, ні які не мали жодного впливу і виконували суто функції виконавців бюджетів регіонального рівня та провідників централізованої державної політики, то тепер об'єднані територіальні громади виступають у якості самостійних гравців, які самі можуть формувати політику регіонального розвитку на своїй території, а також мають інструменти впливу на діяльність інших економічних суб'єктів на цій території. При цьому однією з найбільш суттєвих відмінностей в даному аспекті $є$ саме можливість управління інвестиційною привабливістю власних територій, що дозволяє ОТГ вступати в конкуренцію між собою щодо залучення інвесторів.

Таким чином, поняття конкурентоспроможності ОТГ набуває особливої актуальності в період активного формування інструментарію їх економічного впливу на процеси соціально-економічного розвитку на їх території. Ця особливість $є$ унікальною для України, адже процеси децентралізації системи регіонального управління в країнах Центральної та Західної Європи досить часто не мають можливостей впливу на процеси інвестиційної економічної активності на мікрорівні. Відповідно, дослідження проблематики забезпечення належного рівня конкурентоспроможності ОТГ і є тим завданням, вирішення якого дозволить місцевим громадам досягти належного рівня економічної ефективності та забезпечить їм можливості щодо стимулювання власного економічного зростання в перспективі.

Якщо загалом вести мову про концептуальні основи конкурентоспроможності ОТГ, то необхідно зазначити, що вона «формується завдяки ефективному використанню та управлінню виробничого, фінансового, науково-технічного, інноваційно-інвестиційного, майнового, кадрового потенціалу. Таким чином, конкурентоспроможною територіальною громадою $є$ така громада, у якій місцеві джерела наповнення бюджету, інфраструктурні та кадрові ресурси є достатніми для самостійного забезпечення соціально-економічного розвитку як у короткотерміновій, так i в довготерміновій перспективі» [11, с. 24-25].

Однак саме поняття конкурентоспроможності ОТГ $\epsilon$ не надто конкретним 3 огляду на адміністративно-економічну сутність останніх в системі суб'єктів економічних відносин. I дійсно - 3 одного боку новостворені ОТГ виступають окремими суб'єктами ринку з варіацією інституційних прав регуляторів, а з іншого - одночасно є суб’єктами адміністративного устрою, на території якого й проходять економічні процеси, що формують відносини інших суб'єктів, між якими й відбувається економічна та господарська конкуренція. Таким чином, для того, щоб зрозуміти особливості поняття конкурентоспроможності ОТГ, необхідно з'ясувати концептуальні особливості сутності понять «конкуренція» та «конкурентоспроможність», як економічних категорій. 
Так, необхідно звернути увагу на базову оцінку поняття «конкуренція», здійснене видатним економістом, засновником класичної економічної науки та творцем базових концепцій економічного розвитку - Адамом Смітом, який стверджував, що конкуренція $\epsilon$ «чесним суперництвом між продавцями за більш вигідні умови продажу своїх товарів» [10, с. 68]. Таким чином, дана дефініція заклала основи підходів до розуміння сутності конкуренції в економічних відносинах різноманітних суб'єктів ринку й стала базою для подальшого дослідження та вдосконалення підходів щодо визначення особливостей конкуренції як процесу та конкурентоспроможності, як якісної характеристики суб'єктів економічних відносин.

Значний внесок у дослідження принципів конкуренції та конкурентної боротьби здійснив Джон Стюарт Мілль, який запропонував розглядати конкуренцію, як один з ключових факторів ринкового ціноутворення, що має наслідком позитивний вплив як на продавців, такі на споживачів. Крім того Мілль розглядав конкуренцію в ракурсі стимулюючого фактору у процесі формування капіталів, що приймають участь в процесі виробництва [7, с. 34].

А уже сучасний американський економіст Пол Хейне, один 3 творців теорії конкурентних переваг в результаті своїх досліджень прийшов до висновку, що «конкуренція є прагненням якнайкраще задовольнити критерії доступу до рідкісних благ» [12, с. 113]. При цьому дослідник звернув особливу увагу на той факт, що конкурентоспроможність як така не може бути сформована без належного рівня розвитку ринкового середовища, яке, у свою чергу, стимулює виробників і продавців товарів та послуг на ринку спрямовувати свої зусилля саме на затребувані ринком напрямки діяльності, що забезпечує, з одного боку - збільшення кількості гравців на ринку, які вступають між собою у конкурентну боротьбу, а з іншого - стимулює цих гравців до збільшення обсягу матеріальних та нематеріальних благ, які вони пропонують своїм споживачам в процесі ринкової конкуренції.

Варто також звернути увагу й на дослідження процесів конкуренції видатного австрійського економіста та вченого Фрідріха Августа фон Гайєка, який стверджував що «конкуренція - це процес, за допомогою якого люди отримують i передають знання. Конкуренція веде до кращого використання здібностей і знань. Велика частина досягнутих людських благ отримана саме шляхом змагання, конкуренції. Конкуренція вимагає раціональної поведінки як умови перебування на ринку» $[4$, c. 73$]$.

Проте найбільш важливий, на нашу думку, внесок в дослідження сутності поняття «конкурентоспроможність» здійснив американський дослідник Майкл Юджин Портер, який в процесі вивчення специфіки конкурентоспроможності підприємств розробив сучасну теорію конкурентних переваг, згідно з якою «конкурентоспроможність підприємства може бути оцінена у межах груп підприємств, які належать до однієї галузі» [9, с. 127].

Порте, як бачимо, дослідження принципів конкуренції та конкурентоспроможності, проведені у класичній та сучасній економічній літературі, не дають відповіді на поняття сутності конкурентоспроможності ОТГ та ії характеристик. Відтак виникає необхідність вивчення складових елементів функціонування об'єднаних територіальних громад, які в своїй сукупності і формують конкурентоспроможність ОТГ.

3 іншого боку, конкурентоспроможність ОТГ стосується не лише інвестиційних аспектів їх функціонування, але й нерозривно пов'язана 3 необхідністю розвитку системи соціальноекономічних відносин відповідних територій. Зокрема, значна уваг повинна приділятися й ринку праці, оскільки «при багатоманітності форм власності на майно, грошові кошти тощо, більшість працівників поставлені в умови, коли їхня робоча сила може поєднуватися з засобами виробництва тільки шляхом набуття останніми відповідної форми власності. Так, з аналізу системи трудових відносин у західних країнах видно, що за будь-яких організаційних форм робітники та підприємці повинні мати свободу для напрацювання власних угод, підпорядкованих правовим та іншим обмеженням» [5, с. 208].

Отже, можна стверджувати, що формування конкурентоспроможності ОТГ в сучасних умовах відбувається під впливом комплексу функціональних факторів соціально-економічного розвитку та адміністративного апарату органів місцевого самоврядування, включаючи в себе елементи як ринкової інфраструктури, так і складові фінансового управління, а також - людський капітал, який $\epsilon$ доступним на відповідній території об’єднаної громади. Відповідно, загалом даний комплекс можна 
сформувати у вигляді типової схеми факторів, що впливають на процес формування конкурентоспроможності ОТГ (рис. 1).

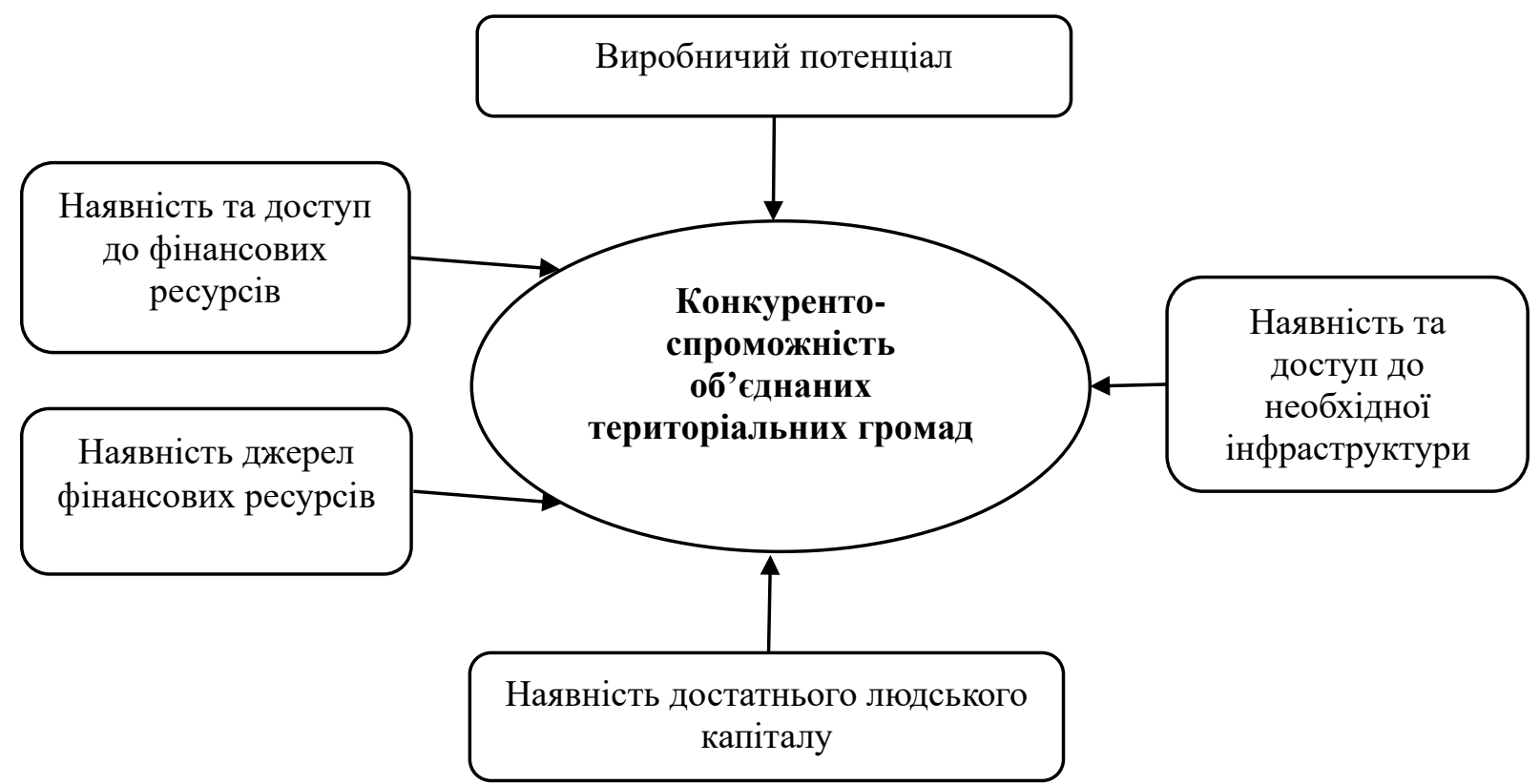

Рис. 1. Фактори формування конкурентоспроможності ОТГ.

Джерело: розроблено автором.

Однак на функціональному рівні такий абстрактний підхід не дає чіткої відповіді на питання щодо конкретних винників, які визначають рівень конкурентоспроможності ОТГ. Такі чинники уже будуть відрізнятися в різних ОТГ, оскільки різний рівень розвитку територій не дозволяє усюди визначати однакові чинники як за якісним, так і за кількісним їх рівнем.

\begin{tabular}{|c|c|}
\hline Чинники конкурен & проможності ОТГ \\
\hline 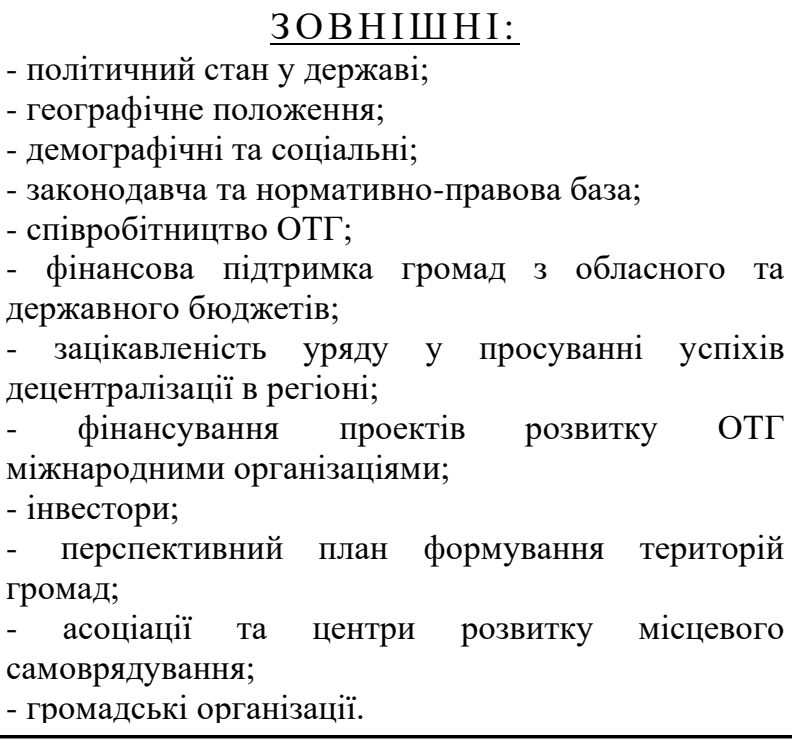 & $\begin{array}{l}\text { ВНУТРІШНІ: } \\
\text { - система та методи управління; } \\
\text { - стратегія соціально-економічного розвитку; } \\
\text { - активна грантова політика громад; } \\
\text { - інвестиційної політики та проектів на } \\
\text { отримання субвенцій від Державного } \\
\text { регіонального розвитку на розвиток } \\
\text { інфраструктури; } \\
\text { - природні та земельні ресурси; } \\
\text { - кадровий склад ОТГ; } \\
\text { - капітал; } \\
\text { - бюджетоутворюючі підприємства та мережі; } \\
\text { - інфраструктура; } \\
\text { - об’єкти соціальної сфери; } \\
\text { - центри надання адміністративних послуг } \\
\text { (ЦНАП). }\end{array}$ \\
\hline
\end{tabular}

Рис. 2. Чинники конкурентоспроможності ОТГ

Дожерело: [2, с. 27].

Головним в даному випадку $\epsilon$ те, що загальна сукупність чинників, що визначають конкурентоспроможність ОТГ, поділяється на внутрішні та зовнішні, оскільки ми змушені в даному 
випадку розглядати територіальні громади не як окремі відособлені елементи економічного та адміністративного устрою, а як комплексні системи, які взаємодіють між собою всередині національного ринку. Відтак на основі поділу цих чинників можна запропонувати наступний їх перелік (рис. 2).

Таким чином конкретна конкурентна позиція об'єднаних територіальних громад в системі соціально-економічного розвитку територій визначається переліком різнопланових чинників, які у своїй сукупності конкретизують загальні фактори формування конкурентоспроможності територіальної громади і мають різноплановий вплив на сам процес розвитку ОТГ.

Висновки та пропозиції. Отже, наявність конкретизованого переліку якісних чинників оцінки конкурентоспроможності ОТГ дає змогу територіальній громаді провести їх оцінку та визначити кількісті параметри і на основі цього аналізу сформувати стратегію досягнення необхідних показників конкурентоспроможності, які таким чином складуть стратегію розвитку громади. 3 іншого боку, без доступу до системи оцінки та аналізу таких параметрів територіальні громади не матимуть можливості формування чітких цілей та завдань стосовно напрямів інвестицій або розвитку інфраструктури, що, зрозуміло, не дозволить їм формувати належний рівень власної конкурентоспроможності.

Однак, як свідчить практика функціонування ОТГ, комплекс чинників конкурентоспроможності повинен опрацьовуватися виключно в аспекті розподілу їх відповідно до ключових факторів формування конкурентоспроможності, незалежно від напрямку впливу кожного конкретного чинника. Адже незалежно від того, чи це є зовнішній, чи внутрішній вплив, окремого системного опрацювання потребують не окремі чинники, а саме системи, які функціонують в рамках сформованих ОТГ, незалежно від того, чи це фінансові, чи трудові, чи інфраструктурні фактори.

3 іншого боку, говорячи про конкурентоспроможність ОТГ не варто відокремлювати її від конкурентоспроможності регіону, в якому вона розташовується. Адже рівень соціальноекономічного та виробничо-промислового розвитку регіонів України досить різний, що накладає відбиток на специфіку умов в яких і сформовані ОТГ. І, відповідно, рівень регіональної економічної конкурентоспроможності областей відбивається на рівні конкурентоспроможності об'єднаних територіальних громад, що, у свою чергу, визначає і різні можливості громад, розташованих у різних регіонах по залученню ресурсів для забезпечення ефективності власного розвитку та функціонування.

Зокрема, як зазначає А. Мельник, «регіональну конкурентоспроможність можна оцінювати за різними ознаками, критеріями i в різних вимірах, вона залежить від конкурентоспроможності базових адміністративно-територіальних одиниць і визначається низкою чинників» [8, с. 23]. Як бачимо, на практиці для конкурентоспроможності ОТГ, яка є залежною від рівнів регіонального розвитку, будуть характерними відповідні регіональні фактори, які стимулюватимуть або ж навпаки - обмежуватимуть можливості територіальних громад щодо позитивної динаміки їх конкурентоспроможності за визначених умов. Це означає, що конкурентоспроможність об'єднаних громад не лише визначається їх територіальним розташуванням, але й іï досягнення спрямоване на динамічний розвиток відповідного регіону держави.

\section{Джерела та література}

1. Бальцерович Л. Свобода і розвиток. Економіка вільного ринку. 2000. С. $23-24$.

2. Білоус Я. Ю. Аналіз чинників конкурентоспроможності об'єднаних територіальних громад. Вісник Східноукраїнського наиіонального університету імені Володимира Даля. 2017. № 6 (236). С. 26-32.

3. Варналій 3. С., Гармашова О. П. Конкурентоспроможність національної економіки: проблеми та пріоритети інноваційного забезпечення. Київ : Знання України, 2015. 463 с.

4. Гайєк Фрідріх А. Конституція свободи. Переклад з англійської: Мирослава Олійник та Андрій Королишин. Львів: Літопис, 2002. 556 с.

5. Дзямулич М. I. Сучасні зрушення в характері та структурі робочої сили. Проблеми формування ринкової економіки: Міжвід. наук. зб. Спец. вип. Управління людськими ресурсами: проблеми теорії та практики. Збірник матеріалів міжнародної науково-практичної конференції «Управління людськими ресурсами: проблеми теорії та практики». Київ: КНЕУ, 2001. С. 206-208.
6. Захарченко
В. I, Захарченко
С. В.. Кластерний підхід
до аналізу i
підвищення 
конкурентоспроможності економіки України та ii регіонів. Вісник Хмельницького нац. ун-ту ; серія : Економічні науки. 2009. № 5, т. 1., С. 53-57.

7. Кириленко В. В. Історія економічних вчень. Навчальний посібник. Тернопіль : Економічна думка, 2007. $233 \mathrm{c}$.

8. Мельник А. Підвищення конкурентоспроможності територіальних громад в умовах реалізації нової регіональної політики України. Вісник Тернопільського начіонального економічного університету. 2019. №1. С. 21-36.

9. Портер М. Конкурентна стратегія. Техніки аналізу галузей і конкурентів. Київ : Наш формат, 2020. 424 c.

10. Сміт А. Дослідження про природу і причини багатства народів. Київ : Наш формат, 2018. 736 с.

11. Співак С., Королюк Т., Мазуренок О. Фактори підвищення конкурентоспроможності об'єднаних територіальних громад. Галицький економічний вісник. 2019. №6 (61). С. 22-29.

12. Хейне П. Экономический образ мышления. Москва : Каталаксия, 1997. 704 с. (рос. мовою).

13. Bilyk R. Role of the Local Authorities in Implementing of Reforms in Ukraine and Ensuring Economic Security of Territories. Intellectual Archive, 2017. Vol. 6. №2. P.10-22.

14. Krugman P. R., Obstfeld M. International Economics: Theory and Policy. Prentice Hall, 2008. 712 p.

15. Lucas R., Stokey N. L., Edward C. Prescott. Recursive methods in economic dynamics. Harvard University Press, 1989. 608 p.

16. Rodrik, Dani. In Search of Prosperity: Analytic Narratives on Economic Growth. Princeton University Press, 2003. $481 \mathrm{p}$.

17. Schultz T. W. The Economics of Being Poor, Cambridge, Massachusetts, Blackwell Publishers, 1993. 484 p.

\section{References}

1. Balcerowicz L. (2000). Svoboda I rozvytok [Freedom and development]. Ekonomika vilnogo rynku - Free market economy. P. 23-24 [in Ukrainian].

2. Bilous Ya. Yu. (2017). Analiz chynnykiv konkurentospromozhnosti ob'ednanyh terytorialnyh gromad [Analysis of the factors of competitiveness of united territorial communities]. Visny`k Sxidnoukrayins`kogo nacionalnogo universytetu imeni Volodymyra Dalya - Bulletin of the Volodymyr Dahl East Ukrainian National University. Vol. 6 (236). P. 26-32 [in Ukrainian].

3. Varnalij Z. S., Garmashova O. P. (2015) Konkurentospromozhnist` nacionalnoyi ekonomiky: problemy ta priorytety innovacijnogo zabezpechennia [Competitiveness of the national economy: problems and priorities of innovation]. Kyiv : Znannya Ukrayiny. 463 p. [in Ukrainian].

4. Hayek Friedrich August. (2002) Konstytucia svobody [Constitution of freedom]. Lviv : Litopys. 556 p. [in Ukrainian].

5. Dziamulych M. I. (2001). Suchasni zrushennya v harakteri ta strukturi robochoyi syly [Modern changes in the nature and structure of the workforce]. Problemy formuvannya rynkovoi ekonomiky : Upravlinnya lyuds`kymy resursamy: problemy teoriyi ta praktyky. Zbirnyk materialiv mizhnarodnoyi naukovo-praktychnoyi konferenciyi «Upravlinnya lyudskymy resursamy: problemy teoriyi ta praktyky» - Problems of market economy formation: Human resource management: problems of theory and practice. Proceedings of the international scientific-practical conference «Human Resource Management: Problems of Theory and Practice». P. 206-208 [in Ukrainian].

6. Zaxarchenko V. I, Zaxarchenko S. V. (2009). Klasternyj pidhid do analizu i pidvyshhennya konkurentospromozhnosti ekonomiky Ukrayiny ta yiyi regioniv [Cluster approach to the analysis and increase the competitiveness of the economy of Ukraine and its regions]. Visnyk Hmelnyckogo nac. un-tu ; seriya : Ekonomichni nauky - Bulletin of Khmelnytsky National un-tu; series: Economic sciences. Vol. 5 (1). P. $53-57$ [in Ukrainian].

7. Kyrylenko V. V. (2007). Istoriya ekonomichnyh vchen [History of economic doctrines]. Ternopil : Ekonomichna dumka. 233 p. [in Ukrainian].

8. Mel`nyk A. (2019). Pidvyshhennya konkurentospromozhnosti terytorialnyh gromad v umovah realizaciyi novoyi regional noyi polityky Ukrayiny [Increasing the competitiveness of territorial communities in the implementation of the new regional policy of Ukraine]. Visnyk Ternopil skogo nacionalnogo ekonomichnogo universytetu - Bulletin of Ternopil National Economic University. Vol. 1. P. 21-36 [in Ukrainian].

9. Porter M. (2020). Konkurentna strategiya. Tehniky analizu galuzej i konkurentiv [Competitive strategy. Techniques of analysis of industries and competitors]. Kyiv : Nash format. 424 p. [in Ukrainian].

10. Smith A. (2018). Doslidzhennya pro pryrodu i prychyny bagatstva narodiv [Research on the nature and causes of the wealth of nations]. Kyiv : Nash format. 736 p. [in Ukrainian].

11. Spivak S., Korolyuk T., Mazurenok O. (2019). Faktory pidvyshchennia konkurentospromozhnosti ob'yednanyh terytorialnyh gromad [Factors of increasing the competitiveness of united territorial communities]. Galyckyj ekonomichnyj visnyk - Galician Economic Bulletin. Vol.6 (61). P. 22-29 [in Ukrainian]. 
12. Heyne P. Ekonomicheskij obraz myshleniya [Economic way of thinking]. Moscow : Katalaksiya, 1997. 704 p. [in Russian].

13. Bilyk R. Role of the Local Authorities in Implementing of Reforms in Ukraine and Ensuring Economic Security of Territories. Intellectual Archive, 2017. Vol. 6. №2. P.10-22.

14. Krugman P. R., Obstfeld M. International Economics: Theory and Policy. Prentice Hall, 2008. 712 p.

15. Lucas R., Stokey N. L., Edward C. Prescott. Recursive methods in economic dynamics. Harvard University Press, 1989. 608 p.

16. Rodrik, Dani. In Search of Prosperity: Analytic Narratives on Economic Growth. Princeton University Press, 2003. $481 \mathrm{p}$.

17. Schultz T. W. The Economics of Being Poor, Cambridge, Massachusetts, Blackwell Publishers, 1993. 484 p.

Стаття надійшла до редакції 18.09.2020 р. 